How to cite: Güler, H.C., Demir, N., Kurbal Ö.F., Babacanoğlu E., The Effect of Dietary Humic Acid on Some Carcass Traits, Meat Quality and Blood Parameters of Japanese Quails Subjected to Pre-Slaughter Feed Withdrawal Stress, J. Anim. Prod., 2019, 60 (1): 15-23, DOI: $10.29185 /$ hayuretim.551705

Research Article

(Araştırma Makalesi)

H. Cem GÜLER ${ }^{1}$

Nejla DEMiR 1

Ömer F. KURBAL

(1)0000-0002-1527-1562

(100000-0002-1500-259X

Elif BABACANOĞLU1

${ }^{1}$ Van Yüzüncü Yıl Üniversitesi, Ziraat Fakültesi,

Zootekni Bölümü, Van, Türkiye

Corresponding author: cemguler@yyu.edu.tr

\section{Kesim Öncesi Açlık Stresine Maruz Bırakılan Bıldırcınlarda Karma Yeme Humik Asit İlavesinin Karkas Parça Randımanı, Et Kalite Özellikleri ve Kan Parametreleri Üzerine Etkileri}

The Effect of Dietary Humic Acid on Some Carcass Traits, Meat Quality and Blood Parameters of Japanese Quails Subjected to Pre-Slaughter Feed Withdrawal Stress

Alınış (Received): 10.02.2019 Kabul tarihi (Accepted): 22.05.2019

\section{öz}

Amaç: Bu çalışmada, kesim öncesi maruz kalınan akut stres (14 saat süreyle aç bırakılma) etmenine karşı, doğal bir yem katkı maddesi olan, farklı oranlarda humik asit (HA) ilavesinin, Japon bıldırcınlarında karkas parça randımanı, et kalite özellikleri ve bazı kan parametreleri üzerine etkilerinin incelenmesi amaçlanmıştır.

Materyal ve Metot: Bu amaçla, toplam 184 adet karışık eşeye sahip Japon bıldırcını, dört gruba ayrılmış, gruplardan biri kontrol $\left(H_{k}, H A=0\right)$ olarak muhafaza edilmiş ve çalışmanın sonuna kadar ticari karma yem (KY) (\%24 protein ve $2900 \mathrm{kcal} / \mathrm{kg} \mathrm{ME;} \mathrm{NRC,}$ 1994) ile beslenmiştir. Diğer 3 gruba, fizyolojik stresin etkilerini önleme amacıyla farklı dozlarda $\mathrm{HA}$ ilavesi yapılmıştır $\left(\mathrm{H}_{1}=\mathrm{KY}+\% 0.10 \mathrm{HA}, \mathrm{H}_{1.5}=\mathrm{KY}+\% 0.15 \mathrm{HA} ; \mathrm{H}_{2}=\mathrm{KY}+\% 0.20\right.$ HA). Kesimden 1 gün önce tüm yem grupları 2 alt gruba ayrılmış (23 bıldırcın/grup) ve hayvanların yarısı 14 saat (açlık stresi, AS) diğer grup 3 saat süreyle aç bırakılmıştır (Kont.).

Bulgular: Açlık stresi ve HA ilavesi karkas ağırlığını etkilememiştir. Tüm et kalite özellikleri AS uygulamasından etkilenmiş, HA uygulaması ise yalnızca $\mathrm{pH}_{24}$ üzerinde etkili olmuştur. Serum toplam protein seviyesi AS grubunda azalırken, LDH artmıştır. HA uygulaması, kontrol grubuna kıyasla $\mathrm{H}_{1.5}$ grubunda en yüksek LDH seviyesini göstermiştir.

Sonuç: Kesim öncesi açlık stresinin bıldırcın göğüs eti kalitesini etkilediği, ancak yeme ilave edilen $\mathrm{HA}^{\prime}$ in önemli bir etkisinin olmadığı görülmektedir.

\section{ABSTRACT}

Objective: In this study, we aimed to investigate the effects of fed supplemented different levels of dietary humic acid (HA), which is a natural feed additive, on cut-up carcass parts yield, on meat quality traits and some blood parameters of Japanese quail exposed to pre-slaughter acute stress (for 14 hours withdrawal).

Material and Methods: For this purpose, a total of 184 mixed Japanese quails were divided into four groups, one of which was kept as a control $\left(\mathrm{H}_{c}, \mathrm{HA}=0\right)$ and was fed with commercial basal diet (BD) (24\% protein and $2900 \mathrm{kcal} / \mathrm{kg} \mathrm{ME;} \mathrm{NRC,} \mathrm{1994)} \mathrm{until}$ the end of the study. Different doses of HA were added to the other 3 groups in order to prevent the effects of physiological stress $\left(\mathrm{H}_{1}=\mathrm{BD}+\% 0.10 \mathrm{HA}, \mathrm{H}_{1.5}=\mathrm{BD}+\% 0.15 \mathrm{HA}\right.$; $\mathrm{H}_{2}=\mathrm{BD}+\% 0.20 \mathrm{HA}$ ). Before slaughter, all dietary treatments were separated into two groups ( 23 quails/group). Half of birds were fed ad-libitum until $3 \mathrm{~h}$ before slaughter (Cont.) while the other half feed was removed (FW) for 14 hours to induced physiological stress.

Results: Feed withdrawal stress and supplemented dietary HA did not affect the carcass weight. All meat quality characteristics were affected by AS treatment, whereas $\mathrm{HA}$ addition was effective only on $\mathrm{pH}_{24}$. Serum total protein levels decreased in the AS group while LDH increased. HA treatment showed the highest LDH level in the $\mathrm{H}_{1.5}$ group compared to the control group.

Conclusion: These results indicate that pre-slaughter feed withdrawal stress affects the quail breast meat quality, however there is no significant effect of supplemented dietary HA. 


\section{GíRiş}

Kesim öncesi fizyolojik stres, etlik piliç endüstrisinin karşılaştığı önemli sorunlardan biridir (Güler ve Yalçın, 2015). Kesim yaşındaki etlik piliçler, ISı stresi, kesim öncesi yemsiz kalma, yakalama, taşıma ve bayıltma gibi birçok akut stres etkeni ile karşı karşıya kalabilir (Ali ve ark., 1999; Sams, 1999). Kesim öncesi maruz kalınan stresin, çiftlik hayvanlarının kas metabolizmasında değişikliklere yol açarak et kalitesinde farklılıklara neden olabileceği uzun zamandır bilinmektedir (Remignon ve ark., 1998). Stres faktörlerinin etkilerine bağlı olarak, özellikle ölüm sonrası glikojen depolarının hızla boşalması, ölüm sertliğini hızlandırarak et kalitesinde azalmaya neden olmaktadır (McKee and Sams, 1997).

Genel olarak, kanatlı kesimhanelerinde dışkı ve patojen kirlenmesi oldukça sık rastlanan bir sorundur. Üreticiler, karkas kontaminasyonunu azaltmak ve olası bulaşmaları engellemek amacıyla, kesimden 8 ila 10 saat önce piliçleri aç bırakmaktadırlar (Wabeck, 1972; Bilgili, 1997). Kesim öncesi yemsiz bırakma birçok metabolik süreci etkiler. Yem yoksunluğu, anabolizmadan katabolizmaya, lipogenezden lipolize geçişi tetiklemekte ve metabolizma hızının düşmesine neden olarak piliçler üzerinde stres oluşturmaktadır (Ali ve ark., 2008). Kesimden önce 8 saat süreyle yemsiz bırakılan etlik piliçlerin, olumsuz refah koşullarına maruz kalmaları nedeniyle, fizyolojik stres düzeylerinin yükseldiği ayrıca aç kalma süresine bağlı olarak canlı ağırlığın düştüğü ve et miktarının azaldığı anlaşılmaktadır (Hamidu ve ark., 2017).

Günümüzde, kalite özellikleri sadece beslenme ve duyusal yönleri değil, aynı zamanda yetiştirme sırasında gıda güvenliği ile çevre ve hayvan refahını da içermektedir. Gıda üreticileri, bu yeni tüketici taleplerine dikkat ederek pazarlarını korumaya çalışmaktadır. Antibiyotiksiz yetiştirilen tavukların üretimi bu seçeneklerden biridir (Contreras-Castillo ve ark., 2007). Kanatlı karma yemlerinde antimikrobiyal bileşiklerin kullanılmasının yasaklanmasıyla birlikte, başta büyüme gelişme olmak üzere, piliç yemlerinde organik kökenli başka alternatiflerin kullanımı yaygınlaşmıştır (Islam ve ark., 2005, Olgun ve ark.,2012). Birçok bitkisel ürün ve bileşenleri, geniş bir antimikrobiyal aktiviteye, antioksidan ve yatıştırıcı özelliklere sahiptir (Demir ve ark., 2005). Bu bağlamda humik asitler de alternatifler arasında yer almakta (Islam ve ark., 2005) ve hümik maddeler humin, humik asit, fulvik asit, ulmik asit ve bazı mikro elementleri içermektedir (Stevenson, 1994). Hümik maddeler toprakta veya humusta stabilize organik maddeden türeyen ve toprakta bitki ve hayvan materyallerinin çürümesi sırasında oluşan kimyasal bileşiklerdir. Hümik asit, suda pratik olarak çözünmeyen ve çok zayıf bir biyolojik aktivite gösteren oldukça kompleks bir yapı maddesidir (Küçükersan ve ark., 2005). Bununla birlikte, humik asidin alkalin maddelerle oluşturdukları tuzlar suda çözünebilir yapıdaki sodyum ve potasyum humatlara dönüşür (Anonim, 2019). Organik maddenin, özellikle bitkilerin ayrışmasından kaynaklanan bir bileşik sınıfı olan humik asitler içme suyu, toprak ve linyitin doğal bileşenleridir. Bakteriyel ve fungal gelişmeyi önleyerek yemdeki mikotoksin seviyesini azaltır. Stres yönetimi, bağışıklık sistemi, anti-enflamatuar aktivite, antiviral özellikler, bağırsak hastalıklarının önlenmesi, özellikle insanlarda ve hayvanlarda diyare, yararlı etkisi olarak tanımlanmaktadır (Tazzoli, 2016). Yemde humik asit ve ilgili ürünlerin kullanılması, bağırsak yapısını düzenleyerek daha iyi yemden yararlanma ve bağışıklık sistemini destekleyerek patojenlere karşı direnç sonucunda sağlık durumunda iyileşmeye neden olmaktadır (Islam ve ark., 2005). Yumurtacı tavuklarda yüksek yerleşim sıklığına bağlı oluşan sosyal stresi önleme amaçlı yeme ilave edilen humat ve organik asidin, kontrol grubuna kıyasla akut stres belirteci olan lenfosit sayısını azaltıcı bir etki gösterdiği ayrıca heterofil ve $\mathrm{H}: \mathrm{L}$ oranında da önemli bir artış oluştuğu aktarılmaktadır. Söz konusu sonuca bağlı olarak, kahverengi yumurtacı tavuklarda meydana gelen sosyal stres ile başa çıkmada karma yeme humat ilavesinin antistresör olarak olumlu etkiler gösterebileceği bildirilmiştir (Çetin ve ark., 2011). Benzer sonuçlar, Yörük ve ark. (2008) tarafından da aktarılmış olup, japon bıldırcınlarında yerleşim sıklığı artıp, hayvan başına düşen kafes alanı azaldıkça canlı ağırlık değişimi, yumurta verimi, yumurta ağırlığı ve yemden yararlanma oranlarının kötüleştiği ancak yüksek yerleşim sıklığından kaynaklanan stres ile mücadelede yeme ilave edilen humat ve prebiyotiklerin önemli derecede iyileşmeye neden olduğu bildirilmiştir.

Japon bıldırcını (Coturnix coturnix japonica), insan gıdası olarak kullanılan et ve yumurta üretimi için yetiştirilen en küçük kümes hayvanı türüdür. Kanatlı etleri arasında en düşük yağ içeriğine sahip olması ve yüksek seviyelerdeki fosfolipid içerdiği nedeniyle tüketiciler arasında en çok tercih edilen alternatif kümes hayvanı etlerinden biridir (Santi ve Kalaikannan, 2017). Ayrıca, hızlı büyüme, düşük yem tüketimi, küçük vücut yapısına bağlı olarak daha az yetiştirme alanına ihtiyaç duyması, hastalıklara direnç, kısa jenerasyon aralığı ve üreme için sınırlı alan gereksinimi gibi özellikleri nedeniyle, bıldırcın genetik 
ve biyolojik çalışmalar için kanatlı çalışmalarında model bir hayvan olarak sıklıkla kullanılmaktadır (Oğuz, 2005; Narinç ve ark., 2013).

Bu çalışmada, kesim öncesi maruz kalınan akut stres (14 saat süreyle aç bırakılma) etmenine karşı, doğal bir yem katkı maddesi olan, farklı dozlardaki HA kullanımının, Japon bıldırcınlarında karkas parça randımanları, et kalite özellikleri, bazı kan parametreleri ve göğüs eti besin madde kompozisyonu üzerine etkilerinin incelenmesi amaçlanmıştır.

\section{MATERYAL ve METOT}

Çalışma, Van Yüzüncü Yıl Üniversitesi, Ziraat Fakültesi, Zootekni Bölümüne ait uygulama-araştırma çiğliğinde bulunan kanatlı hayvan biriminde yürütülmüştür.

Çalışmanın hayvan materyalini karışık eşeye sahip toplam 184 adet Japon Bıldırcını (coturnix coturnix japonica) oluşturmuştur. Denemeyi oluşturan tüm bıldırcınlar, her bölmede 46 bıldırcın olacak şekilde büyütme kafeslerinde 4 farklı bölmeye yerleştirilmiş (150 $\mathrm{cm}^{2} /$ bıldırcın) ve ticari bir firmadan temin edilen, suda eriyebilir toz formda bulunan humik asit (DoctoHumate; toplam organik madde \%25, toplam humik+fulvik asit \%65, suda çözünür $\mathrm{K}_{2} \mathrm{O} \% 6, \mathrm{pH}$ 8-10) ile farklı oranlarda hazırlanan karma yemle beslenmiştir. Bu amaçla, gruplardan birisi kontrol olarak muhafaza edilmiş ve çalışmanın sonuna kadar ticari karma yem (\%24 protein ve $2900 \mathrm{kcal} / \mathrm{kg} \mathrm{ME;}$ NRC, 1994) ile beslenmiştir. Diğer 3 gruba, fizyolojik stresin etkilerini önleme amacıyla farklı dozlarda $\mathrm{HA}$ ilavesi $\left(\mathrm{H}_{1}=\mathrm{KY}+\% 0.10 \mathrm{HA}, \mathrm{H}_{1.5}=\mathrm{KY}+\% 0.15 \mathrm{HA} \mathrm{H}_{2}=\mathrm{KY}\right.$ $+\% 0.20 \mathrm{HA}$ ) yapılmıştır. Çalışma boyunca bıldırcınlar 23 saat aydınlık 1 saat karanlık olacak şekilde standart yetişme koşullarında barındırılmış ve deneme boyunca hayvanlara su serbest olarak verilmiştir. Kesimden 1 gün önce tüm yem grupları 2 alt gruba ayrılmış (23 bıldırcın/grup; 11 dişi, 12 erkek) ve hayvanların yarısı kesim öncesi fizyolojik stres oluşturma amacıyla 14 saat süreyle aç bırakılmıştır. Diğer grup kontrol olarak korunmuş ve bıldırcınlarda minumum ağırlık kaybı için kesimden önce 3 saat süreyle aç bırakılmıştır. Açlık süresine bağlı canlı ağırlık kayıplarını belirlemek üzere, tüm bıldırcınlar açlık öncesi $\left(\mathrm{CA}_{48}\right)$ ve kesim öncesi (açlık sonrası) $\left(\mathrm{CA}_{49}\right)$ tartılarak canlı ağırlıklar belirlenmiştir.

Kesimden önce her alt grupta 20 adet bıldırcın (10 bıldırcın/grup/eşey, toplam 160 adet) servikal dislokasyon ile öldürülmüş ve toplam protein (TP), laktat dehidrogenaz (LDH), glikoz (GL) ve kreatin kinaz (CK) seviyelerini belirlemek üzere $1.5 \mathrm{ml}$ kan örneği alınmıştır. Kesimi takiben, tüm iç organlar çıkartılmış, karkas ve parça ağırlıkları [göğüs, but, kanat ve sırt (sırt+boyun)] belirlenmiş ve tüm karkaslar $+4 \mathrm{C}^{\circ}$ de bir gece dinlendirilmiştir. Karkas randımanı (\%) (KR) kesim canlı ağırlığına; karkas parça randımanları (\%) [göğüs kası randımanı (GR), but kası randımanı (BR), kanat kası randımanı (KKR), sırt randımanı (SR)] ise karkas ağırlığına oranlanarak hesaplanmıştır. Kesimden 24 saat sonra et kalite özelliklerini belirlemek amacıyla bütün hayvanlara ait sol göğüs kasında, et rengi [parlaklık ( $\left.\mathrm{L}^{*}\right)$, kırmızılık (a*) ve sarılık $\left(\mathrm{b}^{*}\right)$ ] Livabond RT 300 portatif renk ölçer (The Tintometer Limited, UK, CIELAB-Illıminant $\mathrm{D}_{65} / 10^{\circ}$ ) cihazı ile belirlenmiş ve et pH'sı ( $\mathrm{pH}_{24}$, Hanna, HI99163N, Hanna Instruments, Romania) saptanmıştır.

Su tutma kapasitesini (STK) hesaplamak üzere, 0,5 g taze göğüs kası dokusu filtre kâğıdı üzerine alınmış ve 2 pleksiglas arasında, 500 psi $\min ^{-1}$ basınçta preslenmiştir. Elde edilen sonuçlar, serbest suyun yüzdesi olarak ifade edilmiştir (Wierbicki ve Deatherage, 1958). İlk tartımları yapılarak derin dondurucuda bekletilen sol göğüs kası örnekleri çözdürme (ÇK) ve pişirme (PK) kayıpları analizleri için bir gece $+4^{\circ} \mathrm{C}^{\prime}$ bekletilmiştir. Tamamen çözünen örneklerde geri tartımlar yapılarak ÇK \% olarak hesaplanmıştır. Aynı örnekler, PK analizi için vakumlu plastik torba içerisinde $+80^{\circ} \mathrm{C}^{\prime}$ lik su banyosunda $25 \mathrm{dk}$ pişirilmiş ve soğutulan örneklerde geri tartımlar yapılarak \%PK hesaplanmıştır (Honikel, 1998). Pişirme kaybı hesaplanan et örnekleri $+4^{\circ} \mathrm{C}^{\prime}$ de bir gece dinlendirildikten sonra sertlik (tekstür) analizleri için yaklaşık $2 \mathrm{~cm}^{3}$ lük et örneğinde, $2 \mathrm{~mm} / \mathrm{s}$ bıçak biniş hızı ile Hdp/wbv, Warner-Bratzler Blade tekstür analiz cihazı kullanılarak sertlik hesaplanmıştır (Papinaho ve ark., 1996).

Sağ göğüs kası (derisiz) örnekleri (10 göğüs kası/grup/eşey, toplam 160 adet) besin madde analizleri yapılmak üzere $-20 \mathrm{C}^{\circ \prime}$ lik derin dondurucuda saklanmıştır. Çözdürülen örnekler homojen hale getirildikten sonra kuru madde (950.48) (KM); kül (920.153) (HK); yağ (960.39-eter ekstrakt) (HY); protein (928.08-Kjeldahl yöntemi) (HP) içerikleri AOAC (2000)'e göre belirlenmiştir.

Çalışmadan elde edilen verilerin istatistik analizinde SAS 9.4 (SAS, 2014) paket programı kullanılmıştır. Gruplara ait ortalamalar arasındaki farklılıkların belirlenmesinde genel doğrusal model (GLM) analizi yapılmış, gruplar arasındaki farklııkların belirlenmesinde Duncan çoklu karşılaştırma testi kullanılmıştır.

\section{BULGULAR ve TARTIŞMA}

Kesimden önce 14 saat süreyle bıldırcınların aç bırakılmalarının, karkas ağırlığı, açlığa bağlı canlı ağırlıkta meydana gelen fire (\%) ve karkas parça 
randımanları (\%) üzerine etkileri Çizelge 1'de verilmiştir. AS ve yeme HA ilavesinin, karkas ağırlığı üzerine önemli bir etkisi olmamakla birlikte, fire (\%) miktarının $A S$, dişi ve $\mathrm{H}_{1}$ grubu piliçlerde önemli bir şekilde $(P<0.05)$ yükseldiği görülmektedir. Açlık stresinin $G R, B R$ ve $S R$ üzerine önemli bir etkisi olmamıştır. Öte yandan, AS grubu piliçlerde KR ve KKR'nin iyileştiği belirlenmiştir. HA ilavesinin karkas parça randımanına önemli bir etkisi belirlenmezken, eşeyin önemli etkileri olduğu görülmüştür $(P<0.05)$. Kanatlı eti üretim endüstrisinde, uygulamalarda farklılıklar görülmekle birlikte, yem ve susuz bırakılma süresi 2 ile 24 saatlik zaman dilimi arasında değişebilmektedir. Kesim öncesi aç bırakma süresi hesaplanırken dikkat edilen nokta, hayvanlarda en az canlı ağırlık ile karkas randımanı kaybına neden olmak ve sindirim sisteminin boşalmasına olanak tanıyacak kadar sürenin öngörülmesidir. Piliçlerin yemsiz bırakılmalarına bağlı olarak refah düzeylerinin bozulması, birçok davranışsal ve fizyolojik tepkilere yol açmakta buna temel neden olarak ise maruz kalınan stres gösterilmektedir (Zuidhof ve ark., 2004). Kanatlılarda açlığa bağlı olarak, aç kalınan her 1 saat için \% 0.22 ile \% 0.56 arasında canlı ağırlık kaybı meydana gelebileceği (Veerkamp, 1978), benzer şekilde etlik piliçlerde 18 saat açlık süresinin \% 1.3-5.3 civarında canlı ağırlık kaybına neden olduğu bildirilmektedir (Contreras-Castillo ve ark., 2007). Bu sonuçlar çalışmamızın bulguları ile uyum içerisinde olup AS grubu piliçlerde, Kont. grubu piliçlere kıyasla $\%$ fire daha yüksek bulunmuştur (sırası ile AS, Kont; \% $6.42 \pm 0.19, \% 2.03 \pm 0.19$ ).

Çalışma bulgularında HA kullanımının $\mathrm{CA}_{48}$ üzerinde önemli bir etkisinin olmadığı, ancak istatistiki olarak önemli olmamakla $(\mathrm{P}=0.460)$ birlikte, $\mathrm{H}_{1}$ ve $\mathrm{H}_{1.5}$ grubunda $\mathrm{CA}_{48}$ 'in daha yüksek olduğu görülmektedir. Bu sonuçlardan, farklı dozlarda HA kullanımının canlı ağırlık üzerinde olumsuz bir etki oluşturmaksızın yem katkısı olarak kullanılabileceği anlaşılmaktadır. Benzer sonuçlar, Šamudovská ve Demeterová (2010) tarafından da aktarılmış olup, etlik piliçlerin $5 \mathrm{~g}^{\mathrm{kg}}{ }^{-1}$ ve $7 \mathrm{~g} \cdot \mathrm{kg}^{-1}$ oranında humik bileşikler ve sodyum humanate ile beslenmelerinin, canlı ağırlık üzerinde farklılığa yol açmadığı, istatistiki olarak önemsiz olmakla beraber uygulama gruplarında kontrole göre daha yüksek canlı ağırlık gözlendiği belirtilmiştir.

Çizelge 1. Açlık stresi ve humik asidin canlı ağırlık, fire, karkas ağırlığı ve karkas parça randımanları üzerine etkisi

Table 1. Table 1. Effects of feed withdrawal stress and humic acid on body weight, live weight loss, carcass weight and carcass parts yield

\begin{tabular}{|c|c|c|c|c|c|c|c|c|c|}
\hline Grup & $\mathrm{CA}_{48}(\mathrm{~g})$ & $C A_{49}(\mathrm{~g})$ & Fire (\%) & $\begin{array}{l}\text { Karkas } \\
\text { Ağırlığı } \\
\text { (g) }\end{array}$ & $\begin{array}{c}\text { Karkas } \\
\text { Randımanı } \\
(\%)\end{array}$ & $\begin{array}{c}\text { Göğüs Kası } \\
\text { Randımanı } \\
(\%)\end{array}$ & $\begin{array}{c}\text { But Kası } \\
\text { Randımanı } \\
(\%)\end{array}$ & $\begin{array}{c}\text { Kanat Kası } \\
\text { Randımanı } \\
(\%)\end{array}$ & $\begin{array}{c}\text { Sırt } \\
\text { Randımanı } \\
(\%)\end{array}$ \\
\hline \multicolumn{10}{|l|}{$A U$} \\
\hline AS & 209.49 & $195.45^{b}$ & $6.42^{\mathrm{a}}$ & 135.73 & $70.01^{\mathrm{a}}$ & 36.02 & 21.77 & $6.78^{a}$ & 35.42 \\
\hline Kont & 211.78 & $209.02^{\mathrm{a}}$ & $2.03^{b}$ & 139.48 & $67.39^{b}$ & 36.36 & 21.36 & $6.53^{b}$ & 35.75 \\
\hline SEM & 2.1 & 1.97 & 0.19 & 1.46 & 0.38 & 0.29 & 0.15 & 0.07 & 0.31 \\
\hline P-değeri & 0.448 & $<.0001$ & $<.0001$ & 0.074 & $<.0001$ & 0.423 & 0.067 & 0.007 & 0.474 \\
\hline \multicolumn{10}{|l|}{ Eşey } \\
\hline Dişi & $231.54^{a}$ & $221.91^{\mathrm{a}}$ & $4.86^{\mathrm{a}}$ & $140.35^{\mathrm{a}}$ & $63.67^{b}$ & $37.40^{\mathrm{a}}$ & $21.86^{\mathrm{a}}$ & 6.71 & $34.02^{b}$ \\
\hline Erkek & $189.72^{b}$ & $185.56^{b}$ & $3.59^{b}$ & $134.87^{b}$ & $73.73^{a}$ & $34.99^{b}$ & $21.27^{b}$ & 6.60 & $37.14^{\mathrm{a}}$ \\
\hline SEM & 2.13 & 1.98 & 0.27 & 1.47 & 0.39 & 0.29 & 0.16 & 0.07 & 0.32 \\
\hline P-değeri & $<.0001$ & $<.0001$ & 0.001 & 0.009 & $<.0001$ & $<.0001$ & 0.009 & 0.211 & $<.0001$ \\
\hline \multicolumn{10}{|l|}{$\mathrm{HA}$} \\
\hline $\mathrm{H}_{\mathrm{K}}$ & 209.09 & 201.68 & $3.86^{\mathrm{b}}$ & 137.12 & 68.67 & 36.61 & 21.25 & 6.64 & 35.50 \\
\hline $\mathrm{H}_{1}$ & 212.57 & 201.47 & $5.23^{\mathrm{a}}$ & 137.64 & 68.73 & 35.31 & 21.76 & 6.83 & 36.10 \\
\hline $\mathrm{H}_{1.5}$ & 213.36 & 204.78 & $4.26^{b}$ & 138.27 & 68.30 & 36.36 & 21.46 & 6.56 & 35.63 \\
\hline $\mathrm{H}_{2}$ & 207.51 & 201.01 & $3.55^{b}$ & 137.41 & 69.09 & 36.50 & 21.78 & 6.61 & 35.10 \\
\hline SEM & 3.01 & 2.80 & 0.28 & 2.09 & 0.55 & 0.42 & 0.22 & 0.09 & 0.45 \\
\hline P-değeri & 0.460 & 0.767 & 0.004 & 0.983 & 0.796 & 0.098 & 0.263 & 0.172 & 0.464 \\
\hline$A U^{*} \mathrm{HA}$ & ÖD & ÖD & ÖD & ÖD & ÖD & ÖD & ÖD & ÖD & ÖD \\
\hline$H A^{*} E$ & ÖD & ÖD & ÖD & ÖD & ÖD & ÖD & ÖD & ÖD & ÖD \\
\hline$A U^{*} E$ & ÖD & ÖD & ÖD & ÖD & ÖD & ÖD & ÖD & ÖD & $*$ \\
\hline$A U^{*} H A^{*} E$ & ÖD & ÖD & ÖD & ÖD & ÖD & ÖD & ÖD & ÖD & ÖD \\
\hline
\end{tabular}

a,b Aynı sütunda farklı harf ile gösterilen özellikler arasındaki farklılıklar önemlidir. ${ }^{*} \mathrm{P}<0.05$

$C_{48}$ : 48. gün canlı ağırlık, CA49: kesim yaşı canlı ağırlığı (49. gün), Fire (\%): 14 saat açlık sonrası canlı ağırlık kaybı, AU: Açlık uygulaması, AS: Açlık stresi (kesimden önce 14 saat süreyle yemsiz bırakma), Kont: Kontrol (kesinden önce 3 saat süreyle yemsiz bırakma), HA: humik asit, KA: karkas ağırlığı, KR: karkas randımanı, GR: göğüs kası randımanı, BR: but kası randımanı, KKR: kanat kası randımanı, SR: sırt randımanı; Hк: Karma Yem, $\mathrm{H}_{1}: \mathrm{KY}+\% 0.10$ humik asit, $\mathrm{H}_{1.5}: \mathrm{KY}+\% 0.15$ humik asit, $\mathrm{H}_{2}: \mathrm{KY}+\% 0.20$ humik asit ilavesi, $\mathrm{SEM}$ : Standart hata, ÖD: önemli değil (P>0.05). 
Çizelge 2. Açlık stresi ve humik asidin et kalite özellikleri üzerine etkisi

Table 2. Effects of feed withdrawal stress and humic acid on meat quality traits

\begin{tabular}{|c|c|c|c|c|c|c|c|c|}
\hline Grup & $\mathrm{pH}_{24}$ & $\begin{array}{c}\text { Parlaklık } \\
\left(L^{*}\right)\end{array}$ & $\begin{array}{c}\text { Kırmızılık } \\
\left(a^{*}\right)\end{array}$ & $\begin{array}{c}\text { Sarılık } \\
\left(b^{*}\right)\end{array}$ & $\begin{array}{l}\text { Çözdürme } \\
\text { Kaybı (\%) }\end{array}$ & $\begin{array}{c}\text { Pişirme } \\
\text { Kaybı (\%) }\end{array}$ & $\begin{array}{c}\text { Sertlik } \\
\left(\mathrm{kg} / \mathrm{cm}^{2}\right)\end{array}$ & $\begin{array}{l}\text { STK } \\
(\%)\end{array}$ \\
\hline \multicolumn{9}{|l|}{$A U$} \\
\hline AS & $5.73^{b}$ & $39.67^{a}$ & 11.04 & $12.37^{\mathrm{a}}$ & $4.87^{a}$ & $23.39^{a}$ & $1.26^{\mathrm{b}}$ & 14.69 \\
\hline Kont & $5.80^{a}$ & $38.69^{b}$ & 10.90 & $11.56^{b}$ & $3.88^{\mathrm{b}}$ & $22.32^{b}$ & $1.40^{\mathrm{a}}$ & 14.17 \\
\hline SEM & 0.01 & 0.31 & 0.23 & 0.20 & 0.23 & 0.19 & 0.04 & 0.55 \\
\hline P-değeri & $<.0001$ & 0.029 & 0.660 & 0.006 & 0.003 & $<.0001$ & 0.009 & 0.514 \\
\hline \multicolumn{9}{|l|}{ Eşey } \\
\hline Dişi & $5.74^{b}$ & 39.60 & $10.53^{b}$ & 12.03 & 4.56 & 22.70 & $1.39^{\mathrm{a}}$ & $15.46^{\mathrm{a}}$ \\
\hline Erkek & $5.80^{a}$ & 38.76 & $11.41^{\mathrm{a}}$ & 11.90 & 4.19 & 23.01 & $1.28^{\mathrm{b}}$ & $13.40^{\mathrm{b}}$ \\
\hline SEM & 0.01 & 0.31 & 0.23 & 0.20 & 0.23 & 0.18 & 0.04 & 0.55 \\
\hline P-değeri & $<.0001$ & 0.058 & 0.008 & 0.654 & 0.269 & 0.244 & 0.042 & 0.012 \\
\hline \multicolumn{9}{|l|}{$\mathrm{HA}$} \\
\hline $\mathrm{H}_{\mathrm{K}}$ & $5.77^{\mathrm{ab}}$ & 40.00 & 11.35 & 12.38 & 4.11 & 23.26 & 1.29 & 14.75 \\
\hline $\mathrm{H}_{1}$ & $5.74^{b}$ & 38.35 & 10.99 & 11.74 & 4.65 & 22.45 & 1.32 & 14.65 \\
\hline $\mathrm{H}_{1.5}$ & $5.80^{\mathrm{a}}$ & 39.04 & 10.84 & 11.84 & 4.68 & 22.98 & 1.34 & 13.28 \\
\hline $\mathrm{H}_{2}$ & $5.76^{\mathrm{ab}}$ & 39.32 & 10.69 & 11.89 & 4.24 & 22.73 & 1.36 & 15.03 \\
\hline SEM & 0.01 & 0.44 & 0.32 & 0.28 & 0.33 & 0.26 & 0.05 & 0.78 \\
\hline P-değeri & 0.029 & 0.080 & 0.539 & 0.429 & 0.641 & 0.147 & 0.819 & 0.411 \\
\hline$A U^{*} \mathrm{HA}$ & $* *$ & ÖD & ÖD & ÖD & ÖD & ÖD & ÖD & $* *$ \\
\hline$H A^{*} E$ & ÖD & ÖD & ÖD & $* *$ & ÖD & ÖD & ÖD & ÖD \\
\hline$A U^{*} E$ & ÖD & * & ÖD & ÖD & ÖD & ÖD & ÖD & ÖD \\
\hline$A U^{*} H A^{*} E$ & ÖD & ÖD & ÖD & ÖD & ÖD & ÖD & ÖD & ÖD \\
\hline
\end{tabular}

$\overline{a, b}$ Aynı sütunda farklı harf ile gösterilen özellikler arasındaki farklılıklar önemlidir. ${ }^{*} \mathrm{P}<0.05,{ }^{* *} \mathrm{P}<0.01$.

AU: Açlık uygulaması, AS: Açlık stresi (kesimden önce 14 saat süreyle yemsiz bırakma), Kont: Kontrol (kesimden önce 3 saat süreyle yemsiz bırakma), HA: humik asit, $\mathrm{H}_{\mathrm{K}}$ : Karma Yem, $\mathrm{H}_{1}$ : $\mathrm{KY}+\% 0.10$ humik asit, $\mathrm{H}_{1.5}$ : $\mathrm{KY}+\% 0.15$ humik asit, $\mathrm{H}_{2}$ : $\mathrm{KY}+\% 0.20$ humik asit ilavesi, $\mathrm{AT}$ : aç ve tok gruplar, SEM: Standart hata, ÖD: önemli değil $(P>0.05)$.

Farklı oranlarda HA kullanımının, bıldırcınlarda ve etlik piliçlerde canlı ağırlık, yem tüketimi ve karkas parça özellikleri üzerinde önemli bir etkisinin olmadığı yapılan pek çok çalışmanın sonucunda da bildirilmektedir (Avcı ve ark., 2007, Kocabağlı ve ark., 2002).

Göğüs eti kalite özelliklerine ait sonuçlar Çizelge 2'te sunulmuştur. AS ve eşey, et kalite özellikleri üzerinde önemli etkilere neden olurken $(\mathrm{P}<0.05)$, farklı oranlarda HA kullanımının et kalite özellikleri $\left(\mathrm{pH}_{24}\right.$ hariç) üzerinde herhangi bir etkisi olmadığı görülmektedir. $\mathrm{AS} \mathrm{pH}_{24}{ }^{\prime}$ ü düşürürken etin daha yumuşak ve parlak $\left(L^{*}\right)$ olmasına neden olmuştur. Kont. grubu piliçlerde $\mathrm{pH}_{24}$ ve sertlik artmıştır. AS grubunda son $\mathrm{pH}^{\prime} \mathrm{n} ı$, kontrol grubuna kıyasla daha düşük bulunması, ayrıca etin daha yumuşak ve et parlaklığının daha yüksek belirlenmesi PSE benzeri et oluşumu ile açıklanabilir. Kesim öncesi aşamada kasların sahip olduğu glikojen düzeyi, kesim sonrası pH'da ki düşüşün derecesini belirlediğinden, et $\mathrm{pH}^{\prime}$ sı ölüm sertliğinin iyi bir göstergesi olarak kabul edilir (Bendal, 1973). Kesimle birlikte, kasın ete dönüşümü sırasında, homeostatik mekanizmaların çoğu bozulur. Kesim öncesi stres koşulları da aynı zamanda homeostatik koşulları ve daha sonra elde edilecek etin kalitesini etkiler (Barbut, 2002). Kesimi takiben et pH'sı, ölüm sertliğinin başlangıç aşamasında çok hızlı bir şekilde düşebilir ve bu durum soluk, yumuşak ve sulu (pale, soft and exudative; PSE) et olarak adlandırılır (Barbut, 1998). Söz konusu durumda, et sıcaklığı hala yüksekken, ilk saat içinde $\mathrm{pH}^{\prime}$ da meydana gelen hızlı düşüş, bazı proteinlerin bozulmasına ve sonuçta sulu görünümlü ete neden olur. Kısmen bozulmuş proteinler, et içindeki suyu yeteri kadar iyi tutamaz ve et yüzeyi ıslak bir görünüm sergileyerek PSE et oluşumuna yol açar (Barbut, 2002). Çalışmanın bulgularında, kesim öncesi uzun süre aç bırakılan bıldırcınlarda et kalitesinin PSE benzeri et oluşumuna bağlı olarak gerilediği söylenebilir. AS'nin olumsuz etkilerini azaltma amacı ile yeme farklı oranlarda eklenen $\mathrm{HA}^{\prime}$ 'in, son $\mathrm{pH}$ hariç, önemli bir etkisinin olmadığı, ancak özellikle $\mathrm{H}_{1.5}$ oranında $\mathrm{HA}$ ilavesinin $\mathrm{H}_{1}$ oranına kıyasla et pH'sının önemli bir şekilde yüksek kalmasına neden olarak, PSE et oluşumu azaltıcı yönde etki gösterdiği söylenebilir. Ancak pH dışında et rengi, sertlik gibi PSE oluşumunu niteleyen diğer özellikler incelendiğinde, farklı oranlarda HA ilavesinin PSE benzeri et oluşumunu azaltıcı bir etkiye neden olmadığı görülmektedir. Öte yandan, son pH değeri için, açlık uygulaması (AU: AS ve Kont.) ve HA ilavesi arasında önemli bir interaksiyon ( $\left.A U^{*} H A\right) \quad(P<0.01)$ saptandığı görülmektedir (Çizelge 1). AU*HA arası ilişkiler incelendiğinde, kontrol grubu piliçleri ile 
$\left(\right.$ AS $^{*} \mathrm{H}_{\mathrm{K}}$ ve Kont $\left.{ }^{*} \mathrm{H}_{\mathrm{K}}\right)$ AS veya $\mathrm{HA}$ uygulama grubu piliçleri arasında istatistiki olarak benzerlikler bulunmakla beraber, genel bir yaklaşım olarak tüm AS grubu piliçlerde HA ilavesinin, Kont. grubu piliçlerine kıyasla (Kont ${ }^{*} \mathrm{H}_{1}$ ve Kont ${ }^{*} \mathrm{H}_{2}$ hariç) son $\mathrm{pH}^{\prime} \mathrm{n} ı$ daha düşük kalmasına yol açtığı söylenebilir (Çizelgede verilmemiştir). Çalışma bulguları ile benzer sonuçlar, Ngoka ve ark. (1982) tarafından da aktarıımı̧ olup, 15 saatlik açlık süresinin, kontrol grubu hindilere kıyasla kas $\mathrm{pH}$ 'sı ve STK'nin azalttığı ve daha yumuşak ete neden olduğu bildirilmiştir. Bu bildirişlere ters olarak, uzun süre yemsiz bırakılmanın (10 saat yemsiz +2 , 4 ya da 6 saat taşıma süresi) karaciğer ağırlığı, glikojen içeriği ve dolaşımdaki glikoz konsantrasyonlarında azalmaya neden olduğu, ayrıca glikojen rezervlerindeki azalmaya bağlı olarak göğüs kası son pH değerinin yüksek kaldığı bildirilmiştir (Warriss ve ark., 1993).

Kanatlı ve domuz eti üretiminde yeme HA ilave edilmesinin, özellikle hızlandırılmış miyoglobin sentezi nedeniyle, et rengini istenen yönde iyileştirdiği bildirilmektedir (Wang ve ark.,2008; Öztürk ve ark.,2012). Humik maddelerin (HS) et rengi üzerine etkileri altında yatan mekanizma kesin olarak bilinmemekle birlikte, bu maddelerin et rengini etkileyebilecek $\mathrm{Fe}, \mathrm{Mn}$ ve $\mathrm{Cu}$ gibi mineralleri az düzeyde de olsa içerdikleri aktarılmıştır (Ji ve ark., 2006). Çalışma bulgularında, yeme HA ilavesinin et rengi üzerinde önemli bir etkisi görülmemiştir $(\mathrm{P}>0.05)$. Benzer bulgular, Kalafova ve ark. (2018) tarafından aktarılmış olup, bıldırcınlarda HA ilavesinin göğüs ve but kaslarında son pH'yı etkilerken (kontrol grubundan daha düşük) her iki etin $L^{*}, a^{*}$ ve $b^{*}$ değerlerinde kontrol grubu ile benzer sonuçlar sergilediği aktarılmıştır. Bu bildirişlere ters olarak, Disetlhe ve ark. (2018), karma yeme HA ilavesinin göğüs eti rengi parlaklığını yükselttiğini aktarmıştır. Araştırıcılar, HA ilavesine bağlı olarak etin genel görünüşünde önemli bir iyileşme meydana geldiğini bildirmektedir. Benzer sonuçlar, yem yerine içme suyuna da farklı dozlarda HS ilavesinin, etlik piliç göğüs ve but etlerinde $L^{*}, a^{*}$ ve $b^{*}$ değerlerinde önemli değişimlere neden olduğunu göstermektedir. Suya ilave edilen $\mathrm{HS}^{\prime}$ lerin performans üzerine önemli bir etkisi olmadığı ancak 15 ve $22.5 \mathrm{~g} /$ kg HS'nin içme suyuna ilavesine bağlı olarak göğüs ve but kaslarında $L^{*}$ ve $b^{*}$ değerinin önemli bir şekilde azaldığı aktarılmıştır (Öztürk ve ark., 2014).

Kanatlı hayvanlar, herhangi bir stres etmenine maruz kaldıklarında bir dizi fizyolojik değişiklik görülmektedir ve bu değişikliklerin önemli bir kısmından adrenal bez sorumludur. Stres koşullarına tepki olarak sinir, endokrin ve bağışıklık sistemi devreye girerek homeostasis sürdürülmeye çalışılır (Siegel, 1995). Strese maruz kalan kanatlılarda ilk olarak sinir sistemi aktive olarak katekolaminler, epinefrin ve norepinefrin salgılanır ve epinefrin metabolik değişikliklerin büyük bir kısmından sorumludur (Siegel, 1980). Stres etmenleri kortikosteron (CS) hormonu salgısını tetiklemektedir. Dolaşıma uzun süreler karışan CS'a bağlı olarak gelişen glukogenesiz ise piliçlerde performans kayıplarına neden olur. CS, bağışıklık sistemi fonksiyonunun bozulmasına ve lenfoid dokuların gerilemesine yol açarak heterofil/lenfosit oranında artışa neden olur. Sonuçta maruz kalınan stres, glikozu metabolize ederek karbonhidrat, protein, lipid ve mineral metabolizmasında değişikliklere neden olur (Virden ve ark., 2009). Bu nedenle, kan parametreleri hayvanlarda sağlık durumu ve stres düzeyinin belirlenmesinde iyi bir gösterge olarak kabul edilir. AS ve HA uygulamalarının kan parametreleri üzerine etkileri Çizelge 3'de sunulmuştur. AS, serum TP düzeyini düşürürken, LDH düzeyini önemli bir şekilde yükseltmiştir. Eşey, GL ve TP üzerinde önemli etkiler göstermiştir.

Farklı HA oranları yalnızca LDH üzerinde etkili olmuş ve kontrol grubuna kıyasla $\mathrm{H}_{1.5}$ grubunda en yüksek düzeyde saptanmıştır. Laktat dehidrogenaz (LDH) ve laktat, hipoksik biyokimyasal parametrelerdir. Bu enzimin hücre dışı etkinliği oksidatif stres koşulları altında artar zira hücre bütünlüğünün lipit peroksidasyon işlemi sırasında bozulduğu bildirilmektedir. Bu durumda da laktik asit ve laktik asit tuzlarının sevilerinde artış olduğu aktarılmıştır (Jovanović ve ark., 2010). Çalışmamız bulgularında AS grubu piliçlerde LDH seviyesindeki artışa bu durum neden olmuş olabilir. Çalışmamız sonuçlarına zıt olarak Delezie ve ark. (2007), kesim öncesi aç bırakılmanın etlik piliçlerde plazma laktat seviyesi üzerinde etkisinin olmadığını aktarırken, çalışma sonuçlarımıza benzer şekilde GL ve CK seviyelerinde önemli bir farklılık olmadığını bildirmiştir. Plazma CK seviyesinin şiddetli stres ve egzersiz altında arttığı bildirilmekle birlikte (Mitchell ve ark., 1992), çalışma bulgularında CK'nın düşük olması hayvanların oluşan stres ile mücadele edebildiklerini göstermiş olabilir. Bir başka çalışmada, soğuk stresine maruz bırakılan etlik piliçlerde, serum LDH seviyeleri değişmezken, TP düzeyinin azaldığı, GL düzeyinin ise arttığı bildirilmiştir (Daneshyar ve ark., 2009). Yapılan çalışmalarda, bıldırcın ve etlik piliç yemlerine farklı dozlarda ilave edilen HA'nın kan serumu TP, GL, CK ve LDH üzerinde olumsuz bir etkisi olmadığı, kontrol grubu ile benzer sonuçlar gösterdiği bildirilmiştir (Rath ve ark., 2006; Avcl ve ark., 2007). 
Çizelge 3. Açlık stresi ve humik asidin kan parametreleri üzerine etkisi

Table 3. Effects of feed withdrawal stress and humic acid on blood parameters

\begin{tabular}{|c|c|c|c|c|}
\hline Grup & Glikoz (mg/dl) & T. Protein (g/dl) & $\mathrm{LDH}(\mathrm{U} / \mathrm{L})$ & Kreatin Kinaz (U/L) \\
\hline \multicolumn{5}{|l|}{$\overline{\mathrm{AU}}$} \\
\hline AS & 259.27 & $2.54^{\mathrm{b}}$ & $1366.88^{\mathrm{a}}$ & 2940.47 \\
\hline Kont & 294.25 & $3.28^{\mathrm{a}}$ & $1094.73^{b}$ & 2553.24 \\
\hline SEM & 12.85 & 0.11 & 85.52 & 154.70 \\
\hline P-değeri & 0.059 & $<.0001$ & 0.028 & 0.082 \\
\hline \multicolumn{5}{|l|}{ Eşey } \\
\hline Dişi & $255.44^{\mathrm{b}}$ & $3.08^{\mathrm{a}}$ & 1192.77 & 2870.54 \\
\hline Erkek & $298.07^{\mathrm{a}}$ & $2.74^{b}$ & 1268.83 & 2623.18 \\
\hline $\begin{array}{r}\text { SEM } \\
\text { P-değeri }\end{array}$ & 12.97 & 0.11 & 85.52 & 154.23 \\
\hline \multirow{2}{*}{\multicolumn{5}{|c|}{$\mathrm{HA}$}} \\
\hline & & & & \\
\hline $\mathrm{H}_{\mathrm{K}}$ & 264.10 & 3.07 & $1047.73^{b}$ & 2858.49 \\
\hline $\mathrm{H}_{1}$ & 306.40 & 3.01 & $1033.78^{b}$ & 2886.49 \\
\hline $\mathrm{H}_{1.5}$ & 274.96 & 2.78 & $1488.17^{\mathrm{a}}$ & 2298.54 \\
\hline $\mathrm{H}_{2}$ & 261.57 & 2.79 & $1353.54^{\mathrm{ab}}$ & 2943.89 \\
\hline $\mathrm{AU}^{*} \mathrm{HA}$ & ÖD & ÖD & ÖD & $\frac{0.152}{O O D}$ \\
\hline$H A^{*} E$ & ÖD & ÖD & ÖD & ÖD \\
\hline$A U^{*} \mathrm{E}$ & ÖD & ÖD & ÖD & ÖD \\
\hline $\mathrm{AU}^{*} \mathrm{HA}^{*} \mathrm{E}$ & ÖD & ÖD & ÖD & ÖD \\
\hline
\end{tabular}

${ }_{a, b}$ Aynı sütunda farklı harf ile gösterilen özellikler arasındaki farklılıklar önemlidir.

AU: Açlık uygulaması, AS: Açlık stresi (kesimden önce 14 saat süreyle yemsiz bırakma), Kont: Kontrol (kesimden önce 3 saat süreyle yemsiz bırakma), $\mathrm{HA}$ : humik asit $\mathrm{H}_{\mathrm{k}}$ : Karma Yem, $\mathrm{H}_{1}: \mathrm{KY}+\% 0.10$ humik asit, $\mathrm{H}_{1.5}: \mathrm{KY}+\% 0.15$ humik asit, $\mathrm{H}_{2}: \mathrm{KY}+\% 0.20$ humik asit ilavesi, SEM: Standart hata, ÖD: önemli değil $(P>0.05)$.

Çizelge 4. Açlık stresi ve humik asidin göğüs eti besin madde kompozisyonu üzerine etkisi

Table 4. Effects of feed withdrawal stress and humic acid on breast meat nutritional composition

\begin{tabular}{|c|c|c|c|c|}
\hline Grup & Kuru Madde (\%) & Ham Kül (\%) & Ham Protein (\%) & Ham Yağ (\%) \\
\hline \multicolumn{5}{|l|}{$\mathrm{AU}$} \\
\hline AS & $27.04^{b}$ & 1.27 & 23.77 & 2.10 \\
\hline Kont & $27.87^{\mathrm{a}}$ & 1.29 & 23.73 & 2.55 \\
\hline SEM & 0.17 & 0.17 & 0.22 & 0.54 \\
\hline P-değeri & 0.0008 & 0.943 & 0.896 & 0.478 \\
\hline \multicolumn{5}{|l|}{ Eşey } \\
\hline Dişi & 27.52 & 1.23 & 23.71 & 2.66 \\
\hline Erkek & 27.39 & 1.34 & 23.79 & 2.99 \\
\hline SEM & 0.17 & 0.17 & 0.21 & 0.54 \\
\hline P-değeri & 0.569 & 0.634 & 0.783 & 0.670 \\
\hline \multicolumn{5}{|l|}{$\mathrm{HA}$} \\
\hline$H_{k}$ & 27.45 & 1.35 & 23.64 & 2.50 \\
\hline $\mathrm{H}_{1}$ & 27.61 & 1.14 & 23.83 & 2.86 \\
\hline $\mathrm{H}_{1.5}$ & 27.20 & 1.39 & 23.80 & 2.12 \\
\hline $\mathrm{H}_{2}$ & 27.57 & 1.24 & 23.73 & 2.84 \\
\hline SEM & 0.23 & 0.24 & 0.31 & 0.76 \\
\hline P-değeri & 0.574 & 0.869 & 0.974 & 0.179 \\
\hline$A U^{*} \mathrm{HA}$ & ÖD & ÖD & ÖD & ÖD \\
\hline$H A^{*} E$ & ÖD & ÖD & ÖD & ÖD \\
\hline$A U^{*} \mathrm{E}$ & ÖD & ÖD & ÖD & ÖD \\
\hline$A U^{*} H A^{*} E$ & ÖD & ÖD & ÖD & ÖD \\
\hline
\end{tabular}

$\overline{a, b}$ Aynı sütunda farklı harf ile gösterilen özellikler arasındaki farkılıılar önemlidir.

AU: Açlık uygulaması, AS: Açlık stresi (kesimden önce 14 saat süreyle yemsiz bırakma), Kont: Kontrol (kesimden önce 3 saat süreyle yemsiz bırakma), $\mathrm{HA}$ : humik asit $\mathrm{H}_{\mathrm{k}}$ : Karma Yem, $\mathrm{H}_{1}: \mathrm{KY}+\% 0.10$ humik asit, $\mathrm{H}_{1.5}: \mathrm{KY}+\% 0.15$ humik asit, $\mathrm{H}_{2}: \mathrm{KY}+\% 0.20$ humik asit ilavesi, SEM: Standart hata, ÖD: önemli değil ( $P>0.05)$.

Bıldırcın göğüs eti besin madde içerikleri Çizelge 4'de verilmiştir. AS yalnızca KM içeriğini etkilerken $(p<0.05)$, eşey farkı ile HA uygulaması tüm besin madde bileșenleri için kontrol grubu ile benzer bulunmuştur. Çalışma bulgularına ait bıldırcın göğüs eti kimyasal kompozisyonu, Genchev ve ark. (2008) 
tarafından aktarılan değerler ile benzerlik göstermekte ve eşeyler arasında besin madde içeriği bakımından istatistiki açıdan fark olmadığı anlaşılmaktadır. Öte yandan, dişi bıldırcınların göğüs eti $H P$ ve KM içeriğinin erkeklere kıyasla daha yüksek olduğunu bildiren çalışmalarda bulunmaktadır (Raji ve ark., 2015). Çalışma sonuçları ile uyumlu olarak, etlik piliçlerin içme sularına farklı oranlarda HS ilavesi yapılmasının, göğüs ve but eti (but eti \% yağ hariç) besin madde içeriğini etkilemediği bildirilmektedir. Ancak, araştırıcılar içme suyuna 450 ppm HS eklenen gruba (HS450, \% 12.14) ait but etlerinde, kontrol grubuna (HSO, \% 10.31) kıyasla \% yağ oranının önemli bir şekilde yükseldiğini, söz konusu bu artışın kontrol grubuna kıyasla HS450 piliçlerinde oksidatif strese karşı direnci düşürdüğünü bildirmektedir (Öztürk ve ark., 2010).

\section{KAYNAKLAR}

Ali A S A, Harrison A P and Jensen J F. 1999. Effects of some antemortem stressor on peri-mortem and post-mortem biochemical changes and tenderness on broiler breast muscle: A review. World's Poult. Sci. J. 55:403-414.

Ali S, Kang G H and Joo S T. 2008. A Review: Influences of Preslaughter Stress on Poultry Meat Quality. Asian-Aust. J. Anim. Sci. Vol. 21, No. $6: 912$ - 916

Anonim, 2019. http://www.teravita.com/Humates/Chapter2.htm

AOAC 2000. Official methods of analysis of the association of official analytical chemist. Vol. I, 15th ed., Arlington, VA.

Avc1 M, Denek N, Kaplan O. 2007. Effects of humic acid at different levels on growth performance, carcass yields and some biochemical parameters of quails. Journal of Animal and Veterinary Advances 6(1), 1-4.

Barbut S. 2002. Poultry products processing: An industry guide. CRC pres.

Barbut S.1998. Estimating the magnitude of the pale soft exudative problem in poultry. J. Muscle Foods, 9, 35-49.

Bendall J R. 1973. Post mortem changes in muscle. Page 243 in: Structure and function of muscle. G. H. Bourne, ed. Academic Press, New York, NY.

Bilgili S F and Hess J B. 1997. Tensile strength of broiler intestines as influenced by age and feed withdrawal. J. Appl. Poultry Res. 6:279283.

Contreras-Castillo C, Pinto A A, Souza G L, Beraquet N J, Aguiar A P, Cipolli K M V A B, Mendes C M I and Ortega E M. 2007. Effects of feed withdrawal periods on carcass yield and breast meat quality of chickens reared using an alternative system. J. Appl. Poult. Res. $16: 613-622$

Cetin E, Güçlü B K, Cetin N. 2011. Effect of dietary humate and organic acid supplementation on social stress induced by high stocking density in laying hens journal of animal and veterinary advances. 10: 2402-2407.

Daneshyar M, Kermanshahi H and Golian A. 2009. Changes of biochemical parameters and enzyme activities in broiler chickens with cold-induced ascites. P. Sci.88:106-110.

Delezie E, Swennen Q, Buyse J and Decuypere E. 2007. The effect of feed withdrawal and crating density in transit on metabolism and

\section{SONUÇ}

Sonuç olarak, bıldırcın yemlerine farklı oranlarda HA ilavesinin canlı ağırlık ve karkas ağırlığı üzerinde önemli bir etkisi olmamakla birlikte, canlı ağırlık kaybının (\% fire) AS, dişi ve $\mathrm{H}_{1}$ uygulama gruplarında önemli bir şekilde yükseldiği görülmektedir. Et kalite özellikleri üzerine $\mathrm{HA}$ ilavesi yalnızca $\mathrm{pH}_{24}{ }^{\prime} \mathrm{ü}$ etkilemiş ve farklı dozlarda HA kullanımı son pH'daki düşüşü etkilemiştir. Öte yandan HA'nın, kesim öncesi oluşturulan stresin olumsuz etkilerini iyileştirici net bir antistres etkisi görülmemiş ve sonuçlar kontrol grubu ile benzer bulunmuştur. Bu nedenle uygulamada açlık süresi ve uygun $\mathrm{HA}$ dozunun belirlenmesi, performans kayıplarını azaltıcı ve et kalite özelliklerini iyileştirici sonuçlar oluşturabilir. Bu yüzden, besi performansı ve et kalitesini iyileştirme amaciyla, daha fazla hayvan üzerinde farklı açlık süreleri ve HA dozlarının denenmesi yararlı olacaktır.

meat quality of broilers at slaughter weight. Poultry Science $86: 1414-1423$.

Disetlhe A R P, Marume U, Mlambo V, and Hugo A. 2018. Effects of dietary humic acid and enzymes on meat quality and fatty acid profiles of broiler chickens fed canola-based diets. Asian-Australas J Anim Sci.,Sep 13, 1-10.

Demir E, Sarica Ş, Özcan M A and Suiçmez M. 2005. The use of natural feed additives as alternative to an antibiotic growth promoter in broiler diets. Arch.Gef., 69 (3). S. 110-116.

Genchev A, Mihaylova G, Ribarski S, Pavlov A, Kabakchiev M. 2008. Meat quality and composition in japanese quails. Trakia Journal of Sciences, Vol.6, No. 4 , pp 72-82.

Güler H C and Yalçın S. 2015. Effects of pre-slaughter physiological stress induced by dietary corticosterone on broiler blood biochemistry and meat quality. XXII European Symposium on the Quality of Poultry Meat and XVI European Symposium on the "Quality of Eggs and Egg Products"

Hamidu J A, Agbehadzi R K, Amexo V E, Brown C A and Adomako K. 2017. Optimizing feed withdrawal time to assess broiler stress and welfare. IJRSAS, Volume 3, Issue 2, PP 1-5.

Honikel K O. 1998. Reference methods for the assessment of physical characteristics of meat. Meat Sci 49( 4): 447- 57.

Islam K M S, Schuhmacher A and Gropp J M.2005. Humic acid substances in animal agriculture. Pakistan Journal of Nutrition 4 (3): 126-134.

Ji F, McGlone J J, Kim S W. 2006. Effects of dietary humic substances on pig growth performance, carcass characteristics, and ammonia emission. J Anim Sci; 84:2482-90.

Jovanović P, Žorić L, Stefanović I, Džunić B, Djordjević-Jocić J, Radenković M, Jovanović M. 2010. Lactate dehydrogenase and oxidative stress activity in primary open-angle glaucoma aqueous humour. Bosnian J.Basic Med. Sci.; 10 (1): 83-88.

Kalafova A, Hrncar C, Zbynovska K, Bucko O, Hanusova E, Kapustova Z, Schneidgenova M, Bielik P, Capcarova M. 2018. The effects of dietary probiotics and humic acid on meat quality of Japanese quail including sex-related differences and economical background. Biologia, Volume 73, Issue 8, pp 765-771.

Kocabagl 1 N, Alp M, Acar N and Kahraman R. 2002. The effects of dietary humate supplementation on broiler growth and carcass yield. Poultry Science 81:227-230 
Kücükersan S, Kücükersan K, Colpan I, Goncuoglu E, Reisli Z, Yesilbag D. 2005. The effects of humic acid on egg production and egg traits of laying hen. Vet. Med. - Czech, 50, (9): 406-410.

McKee S.R., Sams A.R., 1997. The effect of seasonal heat stress on rigor development and the incidence of pale, exudative turkey meat. Poultry Sci., 76, 1616-1620.

Mitchell M A, Kettlewell P J and Maxwell M H. 1992. Indicators of physiological stress in broiler chickens during road transportation. Anim. Welf. 1:91-103.

Narinc D, Aksoy T, Karaman E., Aygun A, Firat M Z, and Uslu M K. 2013. Japanese quail meat quality: Characteristics, heritabilities, and genetic correlations with some slaughter traits. Poultry Science $92: 1735-1744$.

Ngoka D A, Froning G W, Lowry S R, Babji A S. 1982. Effect of sex, age, preslaughter factors, and holding conditions on the quality characteristics and chemical composition of turkey breast muscles. Poultry Sci., 61, 1996-2003.

Oğuz İ. 2005. Japon bıldırcınında (coturnix coturnix japonica) karkas ve et kalitesinin kalıtımı. Hayvansal Üretim 46(1): 34-38.

Olgun O, Cufadar Y, Yıldız A Ö. 2012. Farklı seviyelerde enerji içeren yumurtacı tavuk rasyonlarına humat ilavesinin performans ve kabuk kalitesi özellikleri ile plazma ve tibia mineral düzeylerine etkisi. Hayvansal Üretim 53(1): 1-9.

Ozturk E, Ocak N, Coskun I, Turhan S. \& Erener G. 2010. Effects of humic substances supplementation provided through drinking water on performance, carcass traits and meat quality of broilers. Journal of Animal Physiology and Animal Nutrition, 94: 78-85.

Ozturk E, Ocak N, Turan A, Erener G, Altop A, Cankaya S. 2012. Performance, carcass, gastrointestinal tract and meat quality traits, and selected blood parameters of broilers fed diets supplemented with humic substances. J Sci Food Agric;92:59-65.

Ozturk E, Coskun I, Ocak N, Erener G, Dervisoglu M \& Turhan S. 2014. Performance, meat quality, meat mineral contents and caecal microbial population responses to humic substances administered in drinking water in broilers. British Poultry Science, Vol. 55, No. $5,668-674$

Papinaho P A and Fletcher D L. 1996, The effect of stunning amperage and deboning time an early rigor development and breast meat quality of broilers. Poultry Science 75: 672- 76

Raji A O, Girgiri A Y, Alade N K and Jauro S A. 2015. Characteristics and proximate composition of Japanese quail (Coturnix japonica) carcass in a semi-arid area of Nigeria. Trakia Journal of Sciences 13 159-165.

Rath N C, Huff W E and Huff G R. 2006. Effects of Humic Acid on Broiler Chickens ${ }^{1}$. Poultry Science 85:410-414.

Remignon H, Mills A D, Guemene D, Desrosiers V, Garreau-Mills M, Marche M and Marche G. 1998. Meat quality traits and muscle parameters in high and low fear lines of Japanese quail Coturnix japonica subject to acute stress. Br. Poult. Sci. 39:372-378.
Sams A R.1999. Meat quality during processing. Poultry Science 78:798-803.

Šamudovská A, Demeterová M. 2010. Effect of diet supplemented with natural humic compounds and sodium humate on performance and selected metabolic variables in broiler chickens. Acta Vet. Brno, 79: 385-393.

Santhi D and Kalaikannan A. 2017. Japanese quail (Coturnix coturnix japonica) meat: characteristics and value addition. World's Poultry Science Journal, Vol. 73, June 2017

SAS 2014. SAS/STAT Software: Hangen and Enhanced, Version 9.4 SAS, Inst. Inc., Cary, N.C. USA

Siegel H S. 1980. Physiological stress in birds. Bioscience 30:529-533.

Siegel H S. 1995. Stress, strains, and resistance. Br. Poult. Sci. 36:3-22.

Stevenson F J. 1994. Humus Chemistry: Genesis, Composition, Reactions, 2nd Edition, published by Wiley.

Tazzoli 2016. https://www.allaboutfeed.net/FeedAdditives/Articles/2016/5/Humic-acid-and-its-effect-in-broilerchickens-2806460W/

Veerkamp C H. 1978. The influence of fasting and transport on yields of broilers, Poult. Sci. 57 (3): 634-638.

Virden W S, and Kidd M T. 2009. Physiological stress in broilers: Ramifications on nutrient digestibility and responses. J. Appl. Poult. Res. 18:338-347.

Wabeck C.J. 1972. Feed and water withdrawal time relationship to processing yield and potential fecal contamination of broilers. Poult. Sci. 51:1119-1121.

Wang Q, Chen Y J, Yoo J S, Kim H J, Cho J H, Kim I H. 2008. Effects of supplemental humic substances on growth performance, blood characteristics and meat quality in finishing pigs. Livest Sci; 117:270-4.

Warriss P D, Kestin S C, Brown S N, Knowles T G, Wilkins L J, Edwards J E, Austin S D, Nicol C. 1993. The depletion of glycogen stores and indices of dehydration in transported broilers. Br. Vet. J., 149, 391-398.

Wierbicki E. and Deatherage F E. 1958. Determination ofwater-holding capacity of fresh meats. Journal of Agricultural and Food Chemisto,, 6, 387-92.

Yörük MA, Laçin E, Hayırlı A, Yıldız A. 2008. Humat ve prebiyotiklerin farklı yerleşim sıklığında yetiştirilen japon bıldırcınlarında verim özellikleri, yumurta kalitesi ve kan parametrelerine etkisi. YYÜ Vet Fak Derg. 19: 15-22.

Zuidhof M J, McGovern R H, Schneider B L, Feddes J J R, Robinson F E and Korver D R. 2004. Implications of pre-slaughter feeding cues for broiler behaviour and carcass quality, J Appl. Poult. Sci. 13:335 341. 